\title{
PENGEMBANGAN LEMBAR KERJA SISWA (LKS) PADA MATA PELAJARAN MATEMATIKA SISWA KELAS X SMA
}

\author{
Astuti $^{1}$, Nurhidayah Sari ${ }^{2}$ \\ Universitas Pahlawan Tuanku Tambusai \\ astutimasnur@gmail.com, aie_nurhidayah@yahoo.com
}

\begin{abstract}
The purpose of this research is to develop teaching materials in the form of student worksheet (LKS) kleas X SMA. The resulting LKS can be used by students as a tool to understand the material being studied. LKS is also a source of material that can help students learn independently, so that students are not dependent on the presence of teachers in the classroom.

The subjects of the study were students of class X SMA Negeri 1 Salo academic year 2016/2017 in the even semester with trigonometric material. The data collected in this research is data about teaching tools and learning materials, the need for teaching learning materials, and analysis of the shortage of teaching materials used and later become the study materials in the development.

Based on the results of research and discussion it can be raised research conclusions that LKS developed with trigonometric material developed in accordance with the standards of competence and basic competence. The material presented in the LKS really guides the students to do the activities. LKS developed with trigonometric material is very feasible as a medium of learning. LKS developed with effective trigonomer material on student activities and learning outcomes.

Student learning outcomes so increased from the previous lesson, students' learning mastery level in the classical students also increased from previous material. The developed LKS are made for students to learn more actively and work together with their peers. In the LKS presented some activities and also presented the material in order to learn in a discussion. If students have difficulties teachers are ready to help students. This is what makes the students more understanding and learning more lasting in the memory of students.
\end{abstract}

Keywords: Development, LKS.

Keywords. Student's worksheets,

Abstrak
Tujuan dari penelitian ini adalah untuk mengembangkan bahan ajar berupa lembar kerja siswa (LKS) kleas X SMA. LKS yang dihasilkan dapat digunakan oleh siswa sebagai alat bantu untuk memahami materi yang dipelajari. LKS juga sebagai sumber materi yang dapat membantu siswa belajar mandiri, sehingga siswa tidak tergantung dengan kehadiran guru di kelas.

Subjek penelitian yang diambil yaitu siswa kelas X SMA Negeri 1 Salo tahun pelajaran 2016/2017 pada semester genap dengan materi trigonomtri. Data yang dikumpulkan dalam penelitian ini adalah data tentang perangkat dan bahan ajar pembelajaran, kebutuhan akan bahan ajar pembelajaran, dan analisis kekurangan bahan ajar yang digunakan serta nantinya menjadi bahan kajian dalam pengembangan.

Berdasarkan hasil penelitian dan pembahasan maka dapat dikemukakan simpulan penelitian yaitu LKS yang dikembangkan dengan materi trigonometri dikembangkan sesuai dengan standar kompetensi dan kompetensi dasar. Materi yang disajikan pada LKS sangat menuntun siswa untuk melakukan kegiatan. LKS yang dikembangkan dengan materi trigonometri sangat layak sebagai media pembelajaran. LKS yang dikembangkan dengan materi trigonomeri efektif terhadap aktivitas dan hasil belajar siswa.

Hasil belajar siswa jadi meningkat dari pelajaran sebelumnya, tingkat ketuntasan belajar siswa secara klasikal siswa juga meningkat dari materi sebelumnya. LKS yang dikembangkan dibuat untuk siswa agar belajar lebih aktif dan bekerja sama dengan teman sekelompoknya. Di dalam LKS disajikan beberapa kegiatan dan juga disajikan materi agar bisa belajar secara berdiskusi. Jika siswa terdapat kesulitan guru siap memabantu siswa. Hal ini yang membuat siswa lebih mengerti dan pembelajaran lebih bertahan lama dalam ingatan siswa.

Kata kunci: Pengembangan, LKS

Ilmu pengetahuan tumbuh dan berkembang seiring dengan perubahan waktu, sehingga untuk dapat mengikuti perkembangan dan memahami ilmu pengetahuan tersebut diperlukan keterampilan 
intelektual yang memadai. Keterampilan intelektual ini melibatkan kemampuan bernalar, berfikir sistematis, cermat, kritis dan kreatif. Salah satu ilmu pengetahuan yang sangat memerlukan keterampilan intelektual tersebut adalah matematika.

Matematika adalah salah satu mata pelajaran yang sangat penting dalam dunia pendidikan, karena pelajaran matematika dapat membuat siswa berfikir logis, rasional, kritis dan luas, pernyataan ini sejalan dengan tujuan pendidikan nasional, yaitu: Mempersiapkan anak didik agar mampu menghadapi perubahan dalam kehidupan dan dalam dunia yang senantiasa berubah ini, melalui latihan bertindak atas dasar pemikiran logis, rasional, kritis, dan cermat juga untuk mempersiapkan anak didik agar mampu menggunakan matematika dalam kehidupan sehari-hari dan dalam mempelajari berbagai ilmu pengetahuan.

Menyadari pentingnya peranan matematika maka mengoptimalkan hasil belajar matematika siswa disetiap jenjang pendidikan perlu mendapat perhatian yang sungguh-sungguh agar tujuan dari pendidikan nasional tersebut dapat tercapai. Berdasarkan observasi bahwa hasil belajar matematika siswa belum memuaskan atau masih rendah, dengan hasil rata-rata belajar siswa kelas X SMA Negeri 1 Salo hanya mencapai 65, sedangkan Kriteria Ketuntasan Minimal 70. Rendahnya hasil belajar matematika siswa terutama pada pemahaman konsep disebabkan kurangnya alat untuk menyampaikan materi yang menjadi jembatan oleh guru untuk mencapai tujuan pembelajaran tersebut.

Proses pembelajaran matematika dapat berjalan dengan baik dan dapat mencapai tujuan yang diharapkan, nimimal mencapai KKM yang telah ditentukan sekolah, dan pada akhirnya dapat mencapai tujuan pendidikan nasional untuk itu perlu adanya suatu tindakan atau perubahan yang signifikan dari pihak guru dan siswa.

Dalam proses pembelajaran matematika guru diharapkan dapat menciptakan suasana belajar yang berkesan, menyenangkan dan memiliki berbagai macam sumber belajar. Tetapi yang ditemukan dilapangan banyak guru yang minim mempunyai sumber belajar. Sumber belajar yang digunakan guru yaitu buku paket atau buku yang bersumber dari pustaka dan LKS yang dijual dipasaran. Guru yang baik adalah guru yang memiliki kemampuan menggunakan sumber belajar yang bervariasi tidak hanya menyampaikan materi dengan menggunakan menggunakan buku paket dan menyampaikan contoh penyelesaian soal yang ada dibuku paket.

Pembelajaran yang memiliki minim sumber belajar akan mengakibatkan siswa tidak diberikan kesempatan untuk belajar mendiri cenderung berseumber kepada guru. Proses pembelajaran yang bersumber dari guru akan membuat siswa tidak mandiri dalam belajar, siswa tidak akan mampu menemukan rumus sendiri dan ini mengakibatkan pembelejaran matematika menjadi abstrak.

Salah satu alat yang digunakan guru untuk menjadi jembatan penyampaian materi oleh guru adalah Lembar Kerja Siswa (LKS), tetapi LKS yang digunakan adalah LKS yang dijual dipasaran. LKS yang dijual dipasaran kurang tepat karena hanya berupa kumpulan soal-soal dan berbagai macam bentuk soal. Penyajian materi yang ada di dalam LKS cukup singkat dan padat tanpa adanya panduan 
siswa untuk bekerja sehingga LKS yang dimiliki siswa berkesan sebagai buku yang berisi kumpulan soal.

LKS sebenarnya adalah lembar kerja siswa atau alat yang membantu siswa bekerja. Alat atau LKS ini bisa dikerjakan secara individu atau berkelompok. LKS berisi langkah-langkah yang menuntun siswa untuk menemukan sesuatu, langkah-langkah tersebut tersusun secara sistematis dan beraturan sehingga siswa bekerja dengan benar dan beruntun sesuai yang diharapkan guru. Dengan adanya LKS seperti yang diharapkan memungkinkan untuk mencapai tujuan pembelajaran. LKS merupakan alat untuk menjadi jembatan antara guru dan siswa, menjadi alat komunikasi antara guru dan siswa serta alat komunikasi antara siswa dan siswa. Dengan adanya LKS proses pembelajaran tidak berpusat pada guru, dan siswa bisa bekerja dengan panduan yang sudah ada sehingga menemukan sesuatu yang baru bagi mereka, dan mempunyai kesan yang baik terhadap materi yang disampaikan.

LKS yang digunakan sebabai sumber belajar harus menyajikan soal-soal pemecahan masalah yang sesuai dengan kriteria dari pemecahan masalah yaitu kontekstual, open-ended dan non-rutin. Selanjutnya siswa juga perlu diajarkan langkah-langkah dalam menemukan sesuatu yang baru dalam proses pembelajaran misalnya siswa menemukan rumus sendiri. Berdasarkan latar belakang masalah di atas maka akan dikembangkan LKS yang diharapkan dapat memfasilitasi siswa untuk dapat meningkatkan aktivitas dan hasil belajar siswa.

LKS merupakan lembaran-lembaran yang berisi tugas yang harus dikerjakan oleh siswa. Lembar kegiatan ini biasanya berupa petunjuk, langkah-langkah untuk menyelesaikan tugas (Majid, 2006: 176). Menurut Agustina (2011: 13) LKS adalah "lembaran petunjuk bagi siswa untuk melakukan suatu kegiatan dalam proses pembelajaran, serta daftar tugas dan tempat mencatat hasil pengamatan".

Ada dua macam (LKS) yang dikembangkan dalam pembelajaran di sekolah yaitu 1) Lembar Kerja Siswa Tak Berstruktur. Lembar kerja siswa tak berstruktur adalah lembaran yang berisi sarana untuk materi pelajaran, sebagai alat bantu kegiatan siswa yang dipakai untuk menyampaikan pelajaran. LKS merupakan alat bantu mengajar yang dapat dipakai untuk mempercepat pembelajaran, memberi dorongan belajar pada tiap individu, berisi sedikit petunjuk, tertulis atau lisan untuk mengarahkan kerja pada siswa. 2) Lembar Kerja Siswa Berstruktur. Lembar kerja siswa berstruktur memuat informasi, contoh dan tugas-tugas. LKS ini dirancang untuk membimbing siswa dalam satu program kerja atau mata pelajaran, dengan sedikit atau sama sekali tanpa bantuan pembimbing untuk mencapai sasaran pembelajaran. Pada LKS telah disusun petunjuk dan pengarahannya, LKS ini tidak dapat menggantikan peran guru dalam kelas. Guru tetap mengawasi kelas, memberi semangat dan dorongan belajar dan memberi bimbingan pada setiap siswa. (Indrianto, 1998 : 14-17). Jadi dalam penelitian ini akan dikembangkan LKS berstruktur.

Tujuan penelitian ini adalah 1) Mengembangkan bahan ajar berupa LKS pada siswa SMA Negeri 1 Salo. 2) Untuk mengetahui LKS yang telah dibuat layak digunakan sebagai bahan ajar 
matematika kelas X SMA Negeri 1 Salo. Untuk mengetahui efektifitas LKS yang telah dibuat terhadap aktivitas dan hasil belajar siswa kleas X SMA Negeri 1 Salo.

\section{METODE}

Jenis penelitian yang digunakan adalah penelitian disain (Design Research). Penelitian disain (Design Research) dilaksanakan untuk mengembangkan dan menghasilkan sebuah produk sebagai suatu solusi dari masalah yang berhubungan dengan pendidikan. Pada penelitian ini, produk yang dihasilkan adalah LKS untuk materi matematika semester II kelas X SMA pada materi trigonometri.

Subjek dari penelitian ini adalah siswa kelas X SMA negeri 1 Salo yang terdiri dari lima kelas, dan masing-masing kelas terdiri dari 30 siswa. Uji coba produk diterapkan pada skala kecil yaitu mengambil satu kelas dari lima kelas. Uji pemakaian produk diterapkan pada lingkup yang lebih besar yaitu pada dua kelas lainnya dari kelas X SMA Negeri 1 Salo yang diajarkan oleh guru yang sama.

Teknik pengambilan sampel dalam penelitian ini dengan teknik purposive sample. Sampel yang digunakan dalam penelitian ini sebanyak dua kelas. Sampel yang dipilih langsung oleh guru matematika atas dasar rata-rata hasil belajar dan kemampuan siswa yang hampir sama pada dua kelas tersebut.

Metode pengumpulan data meliputi target, metode, instrumen dan subjek penelitian dapat dilihat pada tabel di bawah ini:

\section{Tabel 1}

\section{Metode Pengumpulan Data}

\begin{tabular}{|l|l|l|l|l|}
\hline No & \multicolumn{1}{|c|}{ Target } & \multicolumn{1}{|c|}{ Metode } & \multicolumn{1}{c|}{ Instrumen } & \multicolumn{1}{c|}{ Subjek } \\
\hline 1 & $\begin{array}{l}\text { Tanggapan siswa terhadap } \\
\text { LKS }\end{array}$ & Angket & Lembar angket & Siswa \\
\hline 2 & $\begin{array}{l}\text { Tanggapan guru terhadap } \\
\text { LKS }\end{array}$ & $\begin{array}{l}\text { Angket dan } \\
\text { wawancara }\end{array}$ & $\begin{array}{l}\text { Lembar angket } \\
\text { Lembar wawancara }\end{array}$ & Guru \\
\hline 3 & Hasil belajar siswa & Tes dan tugas & Soal tes materi & Siswa \\
\hline 4 & Aktivitas siswa & observasi & Lembar observasi & Siswa \\
\hline
\end{tabular}

\section{Analisis Data Penelitian}

1. Analisis data tanggapan siswa dan guru dan analisis data aktivitas siswa dalam pembelajaran .

Data hasil tanggapan siswa dan guru berupa angket dianalisis dengan langkah-langkah sebagai berikut:

$$
\text { skor tanggapan }(\%)=\frac{\text { jumlah skor yang didapat }}{\text { jumlah skor maksimal }} \times 100 \%
$$

Persentase yang telah diperoleh kemudian disesuaikan dengan parameter sebagai berikut (menurut Arikunto 2006):

$$
\begin{array}{ll}
85 \%-100 \% & =\text { Sangat aktif } \\
70 \%-84 \% & =\text { Aktif }
\end{array}
$$


17 Pengembangan Lembar Kerja Siswa (Lks) Pada Mata Pelajaran Matematika Siswa Kelas X SMA, Astuti Astuti, Nurhidayah Sari

$$
\begin{array}{ll}
60 \%-69 \% & =\text { Cukup aktif } \\
50 \%-59 \% & =\text { Kurang aktif } \\
<50 \% & =\text { Tidak aktif }
\end{array}
$$

Penilaian secara klasikasl dihitung dengan menggunakan rumus sebagai berikut (Sudijono 2003).

$$
P=\frac{f}{N} \times 100 \%
$$

$\mathrm{P} \quad=$ Persentase (ketuntasan hasil belajar secara klasikal)

$\mathrm{f} \quad=$ frekuensi yang sedang dicari persentasenya

$\mathrm{N} \quad=$ Jumlah siswa keseluruhan

2. Analisis data hasil evaluasi penggunaan LKS

a. Hasil belajar Siswa

Hasil belajar siswa di analisis secara deskriptif kuantitatif dengan menghitung nilai rata-rata dari nilai tugas dan nilai tes. Nilai akhir atau nilai hasil belajar siswa secara individu dihitung dengan rumus

$$
N A=\frac{A+2 B}{3} \times 100
$$

Keterangan

$$
\begin{aligned}
\mathrm{NA} & =\text { nilai akhir } \\
\mathrm{A} & =\text { nilai tugas } \\
\mathrm{B} & =\text { nilai tes }
\end{aligned}
$$

b. Ketuntasan klasikal

siswa dikatakan tuntas dalam pembelajaran matematikaapabila mencapai nilai $\geq 70$, sesuai dengan nilai KKM matematika yang ditentukan sekolah. Pembelajaran matematika dengan menggunakan LKS ini dianggap tuntas bila mencapai nilai $\geq 75$. Ketuntasan secara klasikal apabila diperoleh nilai siswa yang tuntas $\geq 85 \%$. Persentase ketuntasan siswa secara klasikal dihitung dengan menggunakan rumus menurut Sudijono (2003) dengan rumus sebagai berikut:

$$
P=\frac{f}{N} \times 100 \%
$$

\section{HASIL DAN PEMBAHASAN}

\section{Hasil Efektifitas LKS Terhadap Aktivitas dan Hasil Belajar Siswa}

\section{Hasil Angket Tanggapan Siswa Terhadap LKS}

Hasil analisis menunjukan bahwa sebgaian besar siswa pada kelompok besar yaitu kelas $\mathrm{X}$ IPA SMA Negeri 1 Salo yang berjumlah 24 orang. tanggapan siswa terhadap LKS yang digunakan 
memberikan tanggapan yang positif. Persentase tanggapan siswa secara klasikal dapat dilihat dari tabel 5 .

Tabel 2

Hasil Angket Tanggapan Siswa Terhadap LKS

\begin{tabular}{|l|l|c|}
\hline No & \multicolumn{1}{|c|}{ Kriteria } & Hasil \\
\hline 1 & Sangat Baik & 13 \\
\hline 2 & Baik & 7 \\
\hline 3 & Cukup Baik & 4 \\
\hline 4 & Kurang Baik & - \\
\hline 5 & Tidak Baik & - \\
\hline
\end{tabular}

Persentase tertinggi hasil tanggapan siswa siswa tiap aspek pertanyaan dalam angket adalah pernyataan nomor tiga, empat, lima dan delapan menunjukkan persentase $100 \%$. Pertanyaan nomor tiga, empat, lima dan delapan secara beruntun yaitu siswa setuju tampilan LKS yang diberikan menarik, soal yang ada pada LKS mudah dipahami, LKS yang diberikan dapat menimbulkan motivasi belajar, dan penggunaan LKS dapat mempermudah mengingat dan memahami materi yang dipelajari. Persentase tang terendah pada pernyataan nomor 6. Hanya $70 \%$ siswa yang setuju dengan bahasa yang digunakan. Tangggan siswa secara terperinci tiap butir soal dapat dilihat pada tabel 6 .

\section{Tabel 3}

Rekapiltulasi Tanggapan Siswa Tiap Butir Pertanyaan Angket

\begin{tabular}{|c|c|}
\hline No. Pertanyaan Angket & Persentase Jawaban Siswa \\
\hline 1 & $80 \%$ \\
\hline 2 & $85 \%$ \\
\hline 3 & $100 \%$ \\
\hline 4 & $100 \%$ \\
\hline 5 & $100 \%$ \\
\hline 6 & $70 \%$ \\
\hline 7 & $80 \%$ \\
\hline 8 & $100 \%$ \\
\hline 9 & $75 \%$ \\
\hline
\end{tabular}

Saran perbaikan untuk LKS tidak ada, meskipun demikian siswa memberikan masukan agar LKS yang dikembangkan juga dapat diterapkan pada mata pelajaran lain selain matematika. Berdasarkan pada tabel 5 dan tabel 6 dapat diketahui bahwa secara keseluruhan siswa memberikan tanggapan yang positif terhadap LKS. Persentase tanggapan siswa ini sudah memenuhi indikator 
keberhasilan yang ingin dicapai dalam penelitian yaitu $\geq 81 \%$ tanggapan siswa terhadap LKS yaitu dalam kategori sangat baik.

\section{Hasil Angket Tanggapan Guru Terhadap LKS pada Materi Trigonometri}

Hasil analisis tanggapan guru mengenai LKS pada materi trigonometrimenunjukan tanggapan yang positif dengan penilaian sebesar 92\% dengan kriteria "sangat baik". Hasil angket tanggapan guru dapat dilihat pada tabel 7 di bawah ini:

\section{Tabel 4}

Tanggapan Guru Terhadap LKS dengan Materi Trigonometri

\begin{tabular}{|c|c|c|c|c|c|}
\hline \multirow{2}{*}{ No } & \multirow{2}{*}{ Aspek yang ditanyakan } & \multicolumn{3}{|c|}{ Jawaban } & \multirow{2}{*}{ Keterangan } \\
\hline & & 1 & 3 & 4 & \\
\hline 1 & $\begin{array}{l}\text { Apakah LKS berbasis pada materi } \\
\text { trigonometri sesuai dengan yang Bapak/Ibu } \\
\text { harapkan? }\end{array}$ & & $\sqrt{ }$ & & \\
\hline 2 & $\begin{array}{l}\text { Apakah teks/tulisan dapat dibaca dengan } \\
\text { jelas? }\end{array}$ & & & $\sqrt{ }$ & \\
\hline 3 & $\begin{array}{l}\text { Apakah LKS ini bersifat membantu } \\
\text { memahami materi yang digunakan? }\end{array}$ & & & $\sqrt{ }$ & \\
\hline 4 & $\begin{array}{l}\text { Apakah menurut Bapak/Ibu LKS pada } \\
\text { materi trigonometri mudah digunakan } \\
\text { dalam kegiatan belajar mengajar? }\end{array}$ & & & $\sqrt{ }$ & \\
\hline 5 & $\begin{array}{l}\text { Apakah bahasa yang terdapat pada LKS ini } \\
\text { mudah dipahami? }\end{array}$ & & $\sqrt{ }$ & & \\
\hline 6 & $\begin{array}{l}\text { Apakah LKS tergolong media pembelajaran } \\
\text { yang menarik dan kreatif untuk digunakan } \\
\text { sebagai media pembelajaran? }\end{array}$ & & & $\sqrt{ }$ & \\
\hline 7 & $\begin{array}{l}\text { Menurut Bapak/Ibu apakah penggunaan } \\
\text { LKS dapat membantu mempermudah } \\
\text { dalam memahami materi? }\end{array}$ & & & $\sqrt{ }$ & \\
\hline 8 & $\begin{array}{l}\text { Apakah menurut Bapak/Ibu LKS ini dapat } \\
\text { dipelajari dan digunakan secara mandiri } \\
\text { oleh siswa? }\end{array}$ & & $\sqrt{ }$ & & \\
\hline 9 & $\begin{array}{l}\text { Apakah pokok materi trigonometri yang } \\
\text { terdapat dalam LKS ini sesuai dengan SK } \\
\text { dan KD yang terdapat pada kurikulum? }\end{array}$ & & & $\sqrt{ }$ & \\
\hline 10 & $\begin{array}{l}\text { Menurut Bapak/Ibu apakah penggunaan } \\
\text { LKS materi trigonometri efektif sebagai } \\
\text { salah satu media pembelajaran? }\end{array}$ & & & $\sqrt{ }$ & \\
\hline 11 & $\begin{array}{l}\text { Apakah desain LKS membuat siswa lebih } \\
\text { tertarik untuk belajar? }\end{array}$ & & $\sqrt{ }$ & & \\
\hline 12 & $\begin{array}{l}\text { Apakah Bapak/Ibu setuju LKS diterapkan } \\
\text { pada materi trigonometri? }\end{array}$ & & & $\sqrt{ }$ & \\
\hline 13 & $\begin{array}{l}\text { Apakah LKS layak sebagai alat bantu } \\
\text { pembelajaran pada materi trigonometri? }\end{array}$ & & & $\sqrt{ }$ & \\
\hline & Persentase & & & & $92 \%$ \\
\hline
\end{tabular}

Jawaban guru terhadap angket yang diberikan hampir semua memberikan jawaban yang sangat baik, kecuali pertanyaan nomor 3, 5 8, 11. Komentar guru untuk pertanyaaan nomor 3 menurut 
guru bahwa LKS yang diberikan sudah cukup bagus, tetapi beliau mengharapkan LKS yang diberikan dengan menggunakan kertas yang tebal dan bagus agar LKS ini bisa tahan lama dan awet jika siswa menyimpannya dalam waktu yang lama. Komentar guru untuk pertanyaan nomor 5 yaitu bahasa yang ada di dalam LKS sudah cukup bagus tetapi masih ada bahasa yang tidak dimengerti oleh siswa. Komentar siswa untuk pertanyaan nomor 8 LKS ini tidak bisa di pelajari oleh siswa secara mandiri karena banyak materi baru yang belum pernah dipelajari oleh siswa. Komentar guru untuk pertanyaan nomor 11 desain LKS sudah bagus tetapi masih terdapat kekurangan gambar-gambar yang berkaitan dengan materi.

\section{Hasil Observasi Aktivitas Siswa}

Aktivitas siswa secara individual digolongkan ke dalam empat kategori yaitu aktif, cukup aktif, kurang aktif dan tidak aktif. Keaktifan siswa secara klasikal adalah hanya siswa dengan tingkat keaktifan aktif, cukup aktif dan kurang aktif. Hasil penelitian menunjukan bahwa persentase aktivitas siswa pada pertemuan pertama dan kedua $83 \%$, pertemuan ketiga $88 \%$, pertemuan keempat $94 \%$, kelima dan keenam 96\%. Aktivitas siswa pada saat proses pembelajaran menggunakan LKS dapat dilihat pada tabel 8 di bawah ini:

Tabel 5

Rekapitulasi keaktifan siswa

\begin{tabular}{|l|l|c|c|c|c|c|c|}
\hline No & Kriteria Aktivitas & Pert I & Pert II & Pert III & PertIV & Pert V & Pert VI \\
\hline 1 & Aktif & 12 & 12 & 15 & 18 & 20 & 20 \\
\hline 2 & Cukup Aktif & 8 & 8 & 7 & 6 & 4 & 4 \\
\hline 3 & Kurang Aktif & 4 & 4 & 2 & & & \\
\hline 4 & Tidak Aktif & & & & & & \\
\hline \multicolumn{2}{|l|}{ Persentase } & $83 \%$ & $83 \%$ & $88 \%$ & $94 \%$ & $96 \%$ & $96 \%$ \\
\hline
\end{tabular}

Persentase rata-rata aktivitas siswa secara klasikal ini sudah memenuhi indikator keberhasilan yang ingin dicapai dalam penelitian yaitu $\geq 85 \%$. Aktivitas siswa dalam prosses pembelajaran dalam kriteria aktif dan sangat aktif. Analisis aktivitas siswa tiap jenis aspek aktivitas menunjukkan aspek siswa dalam kerja sama dengan teman satu kelompok untuk menjawab soal diskusi dan membaca materi yang terdapat pada LKS memperoleh persentase tertinggi (100\%) semua siswa melakukan aktivitas ini. Persentase keaktifan siswa yang terendah yaitu terlibat dalam menyimpulkan materi dengan persentase $50 \%$.

\section{Hasil Belajar Siswa Setelah Menggunakan LKS}

Hasil belajar siswa diperoleh dengan memberikan tes tertulis secara individu sebanyak 24 siswa. Ketuntasan belajar siswa kelas $X$ di SMA Negeri 1 Salo dengan $K K M \geq 75$. Nilai yang diperoleh siswa memiliki rata-rata 82 dan ketuntasan secara klasikal diperoleh 92\%. Persentase 
tersebut menunjukan bahwa LKS yang diberikan efektif terhadap hasil belajar siswa. Persentase ketuntasan belajar siswa secara klasikal sudah memenuhi indikator keberhasilan yang ingin dicapai yaitu $\geq 85 \%$. Hasil belajar siswa dapat dilihat pada tabel 9 dibawah ini.

\section{Tabel 6}

Rekapitulasi Hasil belajar Siswa

\begin{tabular}{|c|l|c|}
\hline No & \multicolumn{1}{|c|}{ Variasi } & Nilai \\
\hline 1 & Nilai tertinggi & 96 \\
\hline 2 & Nilai terendah & 72 \\
\hline 3 & Rata-rata & 82 \\
\hline 4 & Jumlah siswa mencapai nilai $\geq 75$ & 22 \\
\hline 5 & ketuntasan klasikal & $92 \%$ \\
\hline
\end{tabular}

Hasil belajar siswa jadi meningkat dari pelajaran sebelumnya, tingkat ketuntasan belajar siswa secara klasikal siswa juga meningkat dari materi sebelumnya. LKS yang dikembangkan dibuat untuk siswa agar belajar lebih aktif dan bekerja sama dengan teman sekelompoknya. Di dalam LKS disajikan beberapa kegiatan dan juga disajikan materi agar bisa belajar secara berdiskusi. Jika siswa terdapat kesulitan guru siap memabntu siswa. Hal ini yang membuat siswa lebih mengerti dan pembelajaran lebih bertahan lama dalam ingatan siswa.

\section{Pembahasan}

\section{Pengembangan Lembar Kerja Materi Trigonometri Kelas X}

Berdasarkan hasil analisis kebutuhan, analisis siswa dan analisis bahan ajar mengidentifikasikan diperlunya bahan ajar yang membuat siswa aktif. Salah satu bahan ajar yang dikembangkan adalah lembar kerja siswa yang dapat mengakomodasikan gaya belajar siswa aktif dengan cara berdiskusi dalam kelompok kecil, penyampaian materi yang terstruktur dan menarik dengan desain yang disesuaikan dengan selera siswa.

Bahan ajar lembar kerja siswa dikembangkan dengan menggabungkan siswa bekerja dengan berdiskusi serta evaluasi secara mandiri dan evaluasi secara kelompok. Setiap komponen kegiatan yang ada dalam LKS mempunyai kelebihan masing-masing. Kegiatan yang dilakukan dengan cara berkelompok bertujuan agar siswa berdiskusi untuk mempelajari materi yang ada pada LKS. Evaluasi dengan kelompok bertujuan untuk mengevaluasi hasil diskusi yang dilakukan kelompok. Evaluasi mandiri bertujuan untuk mengevaluasi pemahaman materi secara individu dan siswa bisa mengukur kemampuannya sendiri.

Lembar kerja siswa yang dikembangkan didesain dengan warna yang menarik dan gambar yang bagus. Ini bertujuan agar lembar kerja siswa yang dikembangkan siswa tertarik dan termotivasi untuk membuka dan membacanya serta disimpan sebagai bekal ilmunya nanti. 
Lembar kerja siswa yang sudah dikembangkan kemudian mendapatkan kritik dan saran dari pakar pendidikan matematika. Setelah direvisi sesuai dengan saran pakar kemudian diujicobakan sesuai dengan langkah-langkah menurut ploomp. Uji coba yang dilakukan kemudian dikumpulkan data tanggapan, aktivitas, dan hasil belajar siswa. Setelah lembar kerja siswa yang dikembangkan melalaui proses tersebut maka lembar kerja siswa yang dikembangkan dapat diterapkan dalam pembelajaran secara umum.

\section{Kelayakan Lembar Kerja Siswa}

Penilaian lembar kerja siswa yang sudah dikembangkan dinilai oleh pakar pendidikan matematika berdasarkan pemikiran rasional belum berdasarkan fakta dilapangan. Jika terjadi ketidaksesuaian maka akan dilakukan perbaikan dengan meninjau kembali bahan ajar. Penilaian pakar sangat layak sebagai bahan ajar untuk materi trigonometri. Proses kelayakan lembar kerja siswa yang dikembangkan dengan menggunakan teori poloomp. Setiap langkah pada teori ploomp dilaksanakan dan kemudian direvisi sesuai dengan kritik dan saran yang didapatkan. Hasil akhir lembar kerja siswa yang dikembangkan sesuai dengan teori polomp memenuhi kriteria layak sebagai bahan ajar untuk siswa kelas X pada materi trigonometri.

\section{Uji Coba Lembar kerja Siswa}

Uji coba lapapangan dilakukan untuk mengetahui keefektifan bahan ajar materi trigonometri kelas X SMA. Keefektifan bahan ajar lembar kerja siswa dalam penelitian yaitu kekefektifan terhadap aktivitas dan hasil belajar siswa. Uji coba lapangan terdiri dari 24 siswa. Secara keseluruhan pembelajaran menggunakan lembar kerja siswa yang telah dikembangkan efektif terhadap aktivitas siswa. Keefektifan tersebut terlihat dari analisis yang menunjukan aktivitas siswa secara kalisikal pada pertemuan pertama sampai pertemuan keenam meningkat dengan hasil akhir keaktifan siswa mencapai 96\%. Hasil keaktifan siswa sudah melebihi dari indikator keberhasilan yang sudah ditetapkan yaitu $\geq 85 \%$. Aktivitas siswa dalam kegiatan pembelajaran termasuk kategori sangat aktif.

Salah satu hal yang menyebabkan aktivitas siswa adalah proses pembelajaran yang dilakukan secara berkelompok. Selama proses tesebut siswa saling berinteraksi dan bekerja sama untuk mendiskusikan materi dan soal yang ada pada LKS. Pembelajaran siswa secara berkelompok membuat siswa yang malu menjadi lebih nyaman untuk bertanya kepada teman sekelompoknya. Adanya diskusi kelompok membuat siswa lebih aktif dan temotovasi untuk mengikuti proses pembelajaran. Sesuai dengan pendapat Amri dan Ahmadi (2010) diskusi membantu agar pelajaran dikembangkan terus menerus atau disusun berangsur-angsur dan merangsang semangat bertanya dan minat perorangan.

Penyebab lain ketercapaian indikator keberhasilan aktivitas siswa yaitu dalam kegiatan pembelajaran siswa dituntut untuk mengerjakan soal latihan secara berkelompok dan individu. Kegiatan pembelajaran ini memicu atau mendorong siswa untuk berkompetisi dalam menyelesaikan soal evaluasi tersebut. 
Keaktivan siswa secara klasikal memenhui kriteria sangat aktif namun masih ada siswa yang termasuk ktiteria cukup aktif. Salah satu penyebabnya adalah keterbatasan waktu untuk tanya jawab. Siswa yang termasuk kriteria cukup aktif juga dikarenakan faktor internal siswa yaitu siswa memiliki karakteristik pendiam dan kurang merasa percaya diri sehingga tidak mau menunjukan kemampuannya. Siswa yang memiliki faktor tersebut perlu diberikan motivasi agar berani bertanya dan mengutarakan pendapat sehingga lebih aktif dalam pembelajaran.

Lembar kerja siswa yang dikembangkan juga efektif terhadap hasil belajar siswa. Keefektifan tersebut terlihat dari hasil belajar siswa. KKM yang ditentukan oleh sekolah adalah 75 . Nilai siswa yang tertinggi 76 dan terendah 72. Siswa yang mencapai ketuntasan 22 orang dan tidak tuntas 2 orang. Ketuntasan klasikal dalam penelitian ini mencapai 96\% melibihi batas ketuntasan klasikal dalam penelitian yatiu $85 \%$.

Faktor yang menyebabkan siswa tuntas pada peroses pembelajaran adalah lembar kerja siswa yang dikembangkan menuntut siswa untuk melakukan kegiatan yang ada pada LKS. Setiap kegiatan yang ada pada LKS menuntun siswa untuk menemukan rumus sendiri atau konsep sendiri. LKS juga menuntun siswa pada proses pengambilan kesimpulan sehingga proses melakukan kegiatan yang ada pada LKS akan teringat lama dalam ingatan siswa. Lembar kerja siswa yang dikembangkan juga berisikan tes secara berkelompok dan secara individu. Tes yang yang ada pada LKS membuat siswa menjadi lebih paham terhadap materi. Karena seriap hasil evaluasi yang dikerjakan oleh siswa dievaluasi lagi oleh guru dengan cara presentasi didepan kelas. Hal ini membuat siswa bisa mengukur kemampuannya dan siswa bisa mengkritik atau bertanya jika jawaban mereka tidak sesuai dengan yang dipresentasikan.

\section{KESIMPULAN}

Berdasarkan hasil penelitian dan pembahasan maka dapat dikemukakan simpulan penelitian sebagai berikut: LKS yang dikembangkan dengan materi trigonometri dikembangkan sesuai dengan standar kompetensi dan kompetensi dasar. Materi yang disajikan pada LKS sangat menuntun siswa untuk melakukan kegiatan, LKS yang dikembangkan dengan materi trigonometri sangat layak sebagai media pembelajaran. LKS yang dikembangkan dengan materi trigonomeri efektif terhadap aktivitas dan hasil belajar siswa.

Berdasarkan hasil penelitian saran yang dapat disampaikan dalam penelitian ini sebagai berikut: Guru sebaiknya meningkatkan dan memastikan siswa sudah membaca dan memahami petunjuk dalam melaksanakan kegiatan yang ada pada LKS. Persiapan yang matang dan pengolahan waktu yang baik dangat diperlukan dalam menggunakan LKS materi trigonometri. Pengembangan LKS yang direkomendasikan dikembangkan untuk materi yang membuat siswa untuk melakukan kegiatan atau aktifitas tertentu. 


\section{DAFTAR PUSTAKA}

A.M Sadirman. 2009. Interaksi dan motivasi Belajar Mengajar. Jakarta: PT Rajawali Pers. Anonimus. 2007. Panduan Lengkap KTSP. Yogjakarta: pustaka Yustisia.

Agustina, Dewi. 2011. Studi Komparasi Metode Pembelajaran Teams Games Tournament (TGT) Dan Student Teams-Achievement Divisions (STAD) dilengkapi Lembar Kerja Siswa (LKS) Terhadap Prestasi Belajar Siswa Materi Pokok hidrokarbons Kelas X SMA batik 1 Surakarta Tahun Ajaran 2010/2011 (Skripsi). Surakarta: Universitas Muhammadiyah Surakarta.

Aleks Maryunis. 2003.Upaya Peningkatan Hasil belajar Matematika Siswa SLTP Menggunakan Strategi Pemetaan Informas., Forum Pendidikan

Anas Sudijono. 2003. Pengantar Statistik Pendidikan. Bandung: PT Raja Grapindo Persada.

Arikunto,Suharsimi. 2006. Prosedur Penelitian Suatu Pendekatan Praktik. Jakarta: Aneka Cipta.

2009. Dasar-dasar Evaluasi Pendidikan. Jakarta: Aneka Cipta.

Daryanto: 2008. Evaluasi Pendidikan. Jakarta: Rineka Cipta.

Hartati. 2002. Pengembangan Lembar Kerja Siswa Matematika Berbasis Web. Bandung: UPI

Indriyanto, L. 1998. Pemanfaatan Lembar kerja Siswa dalam pengajaran matematika

Sebagai Upaya Peningkatan Prestasi Belajar Matematika. Skripsi Pada IKIP Semarang. Tidak diterbitkan.

Majid, Abdul. 2006. Perencanaan Pembelajaran. Bandung: PT Remaja Rosdakarya

Mulyadi. 2002. Auditing. Edidi keenam. Cetakan pertama. Jakarta: Salemba Empat

Sholeh, Muhammad. 1998. Pokok-pokok Pengajaran Matematika di Sekolah. Jakarta: Departemen Pendidikan dan Kebudayaan RI

Sugiyono. 2006. Statistika Untuk Penelitian. Bandung: Alfabeta

Trianto.2010. Mendesain Model Pembelajaran Inovatif-Progesif. Jakarta: Kencana 